\title{
Myth in a Paradoxical Context
}

\author{
Aslan Zhalelovich Zhaksylykov ${ }^{1}$, Ainur Serikbaikyzy Aitmukhanbetova ${ }^{1} \&$ Indira Kairatkyzy Azimbayeva ${ }^{1}$ \\ ${ }^{1}$ al-Farabi Kazakh National University, Kazakhstan \\ Correspondence: Aslan Zhalelovich Zhaksylykov, al-Farabi Ave., 71, Almaty, 050038, Kazakhstan. E-mail: \\ Aslanj54@mail.ru
}

Received: March 23, $2015 \quad$ Accepted: April 27, $2015 \quad$ Online Published: July 30, 2015
doi:10.5539/ass.v11n19p42
URL: http://dx.doi.org/10.5539/ass.v11n19p42

\begin{abstract}
The article deals with the integrality and paradoxes of the global myth used by Ch. Aitmatov in his novel "The Scaffold" and in the story "The White Ship" ("After the fairy tale") for the actualization of the most important moral issues which are necessary for understanding the survival of the mankind in the modern racing condition of arms and environmental disaster. The peculiarities of the writer's mythpoetical thinking, his ability to show a tough connection between the good and the evil in the paradoxical clash of ideas are revealed in the article. Aitmatov's contribution not only to the aesthetic potential of the Kirgiz literature, as well as to the global one, especially in terms of framing symbolic prose by parable forms, ability to literally generalize significant moralphysiological state of the community is shown clearly.
\end{abstract}

Keywords: myth, pattern, idea, ideology, moral issue, culture, ethnos

\section{Introduction}

Ch. Aitmatov was the most mythological writer among the writers of the Soviet national literature. The sustainable and consecutive application of forms of the mythologized thinking, the development of means of literal symbolic and paradigmatic saying, the paradoxical combination in mythological moral focus of the epic past and the present, spiritual rehabilitation of the religious personality in ("The White Ship", "Snowy substation", "The Scaffold") eventually led Ch. Aitmatov to the conventions of a fantastic plot in the novel "Cassandra's Brand". The logic of the development of his magic realism was shown in the following way: from socialist realism in "The first teacher" to magic realism in "The Scaffold" and thinking by conditional and symbolic images in the novel "Cassandra's Brand". This aesthetic movement in the writer's creativity was commented on in the monographs (Zhaksylykov, 2013, p. 329)

The mythologized poetic thinking on paradigms, signs, symbols of traditional ethno cultures in Ch. Aitmatov's works was noted by critics and literary critics of the country. Acuteness of the moral problem in the novel "Cassandra's Brand" which is normal for former poetics of the writer, increased humanistic demands to the modern person, emotionality, developed empathy to the hero gave the way to stylistics and the genre principles of a conditional and symbolic narration.

\section{Materials and Experiment Methods}

Ch. Aitmatov's novel "The Scaffold" is one of his most actual works addressed to a contemporary context, carrying very significant revelations, which are of great importance in space time of moral and ontological genesis of mankind. The reason is that the writer managed to reach the level of the biggest dialogue of mankind in his stories-saying about its spiritual formation, tragic, difficult, immense in time, incomplete, but after all formation. The main religions of mankind, Judaism, Christianity, Islam, Vedic religions, the Buddhism and Daoism were also formed as a result of the saying. (Schure, 1990, p. 419) Formation of these religions meant not only an institutionalization of the ritual and ceremonial party, aging of ideology and its laicization, not only evolution of ethnic and quasi-ethnic cultures, but forming of internal patterns of life of the mankind's spiritual body, their movement in a multidimensional spiritual microcosm with a potential exit to macro level of the Universe. The concept of pattern of life was introduced to the synergy by Capra Fritjof. (Capra, 2003, p. 336) In the process of this global movement of ideas which was accompanied by various wars, collision of cultures, enrichment of formations, crisis of civilizations, a collapse of the whole races and emergence of syncretic, marginal consortium at matrix, information and verbal level crystallization of the major paradigms such as ideologies, myths, fable, allegories, and paradoxes occurred. It is these paradigms that represent the essence of 
the most important spiritual revelations of the mankind: Veda, Upanishad, Bibles, Koran, Dao Dye Tsinan and Sutra. One should not forget about folklore fund where spiritual experience of the archaic mankind was revealed which passed stages of animism, magic, fetishism, shamanism, hieratic religions, lunar and solar cults. The symbolic aspect of stratification of actions of religious devotees should be referred to paradigmatic: Moisey's wandering, Christ's ascending Golgotha, Mohamed's self-determination, meditation of Buddha, renunciation of Krishna, Lao Zi's inaction and etc. The symbolic aspect of the founder's actions is read by adherents and is not explained in proper way and it leads to differentiation of any religion into sects, the directions and faiths. According to the scholars reading a text is always interpretation of ideas. (Muchnik, 1995, p. 181) Canonization of one of the readings is already history that is consolidation, a form of materialization, transformation into psycho-type, a matrix form that is a pattern. Though there is always a process of an erosion of forms (the second law of thermodynamics works in the sphere of ontology). Thus, the history of mankind is a battle and synergetic movement of ideas. Religion, literature, philosophy, ideology always participates in this movement which is different aspects of unique ancient energy - the myth. This battle, disintegration and consolidation of forms in foreseeable history of mankind are characterized by incandescent of some ideologies. This incandescent, socially, ideologically significant acuteness of ideologies appears to be so great that is discharged in society by revolutions, wars, local conflicts or at least, fierce disputes. (There is no end to examples-A. Zh.)

The most gifted writers are connected with this major dialogue of the mankind (Thomas Mann, L. N. Tolstoy, F. M. Dostoevsky). Here religious-philosophical and creations rich with religious connotations are not rarely created. (Mann, 1991, p. 720) Chingiz Aitmatov is not an exception here. Aitmatov's "The Scaffold" provoked the disputes at the time. It is far not by accident. The polemic semantic charge of the novel has two-layers: firstly it was directed against the totalitarian ideology of the Soviet Union, splitting it, forming other background of interpretation of the dominating doctrine, secondly he paradoxically made a display of the east, Turkic stereotype, historically alienated from the main Christian paradigm-a god becoming a human. Ch. Aitmatov's novel can be considered as a global fable. The reason is that the story of the writer is connected with the spiritual dialogue of mankind, at the same time it is its continuation, reflection and paradoxical refraction in our world. The myth as a firm form, as refraction in the modern world can't but be a paradox. Moreover, it is a multidimensional paradox. Only providential action of the storyteller needed. Though, it is another story.

\section{Results and Discussion}

Avdii Kallistratov is one of the main heroes of the novel, internally contrasted to Jesus Christ. This altruist, seminarian, a half-educated person is dialogically connected with Jesus Christ, this connection is moral, imperative, traditional, at the same time polemic because Avdii had an idea of new religion, so-called "GodTomorrow" Avdii is fiercely against of a canon, in this sense he is a Protestant in Orthodoxy, that means he is a secessionist. The dispute with the canon-coordinator displays it well. (Aitmatov, 1971, pp. 72-77) Avdii, internally aimed at the performance of his mission can't but understand that steadily moves to the crosssacrificial crucifixion no matter in what form it would occur. To some extent he is the savior because he considers that his aim is to rescue fallen souls, addicts and alcoholics. At the same time his destiny brought him to Kazakhstan, the world of the good-natured nomads. Jesus Christ's victim in the history created a set of tragic analogs, where global idea of atonement through suffering and saving of god becoming human were reflected as in micromodel. So-called Christ exists in our world (Vissarion, Maria Davey Christos, etc. - A. Zh.) ("A Little Grain of the Word of Vissarion Presenting the Last Testament of the Heavenly Father who Sent Him", 1993) Connection between Avdii and Jesus Christ, especially his spiritual moving to Jerusalem in the time of Golgotha, generates side meanings, valuable associations displaying serious intellectual layers in the process of the development of the action. One of them is despair of the victim of Avdii crucified by recidivists and alcoholics because only the she-wolf Akbara appeared to be the witness of a crucifixion. This scene is well known for its paradox that the animal acts more human than the people who scenically surrounded Avdii, those whom he wanted to rescue. In a present context, in understanding of Aitmatov, people are potential animals, natural animals are victims. The significant thought is based on the energy of the myth: since the Bible times people had considerably been dehumanized, that means they had been degraded. The novel "Scaffold" expressively shows Avdii's crucifixion, mass destruction of saiga antelopes, the death of wolves Akbara and Tashchainar. The tragic aspect of the novel is genre-forming principle, through which an eschatological form is steadily formed.

The religious paradigmatics can't do without the idea of evil spirit or the absolute evil, which is Satan. In the novel this idea was passed to a significant lacuna, a reticence in connection with images of Grishan and Ober-Kandalov, the characters who are consciously professing the principle of the evil. Ober-Kandalov is Grishan's logical continuation; he is continued by the planned idea of fascism. Thus the idea of the evil in the novel is metaphorically developed, however isn't mystified as it is made by M. Bulgakov and D. Andreev in their 
works (Bulgakov, 1987) In this regard it is possible to claim that Ch. Aitmatov in esthetics is the mythological rather than the mystical strategist.

Avdii's connection with Akbara, the she-wolf, is a long line of unclear associations, the lacunas the meaning of which can be explained by the Turkic animalistic myth poetics. (Zhetpisbaeva, 1999, p. 288) First of all it is an ontological intersection where the Christianity and tengrian realism meet. In a literal situation it is considerably misunderstanding, that is a blur of signs, historically it is an emergence of a chimerical manichaeanism. However, Ch. Aitmatov is known for creating images of Akbara and Tashchainar that take a start from M. O. Auezov's story "Grey Fierce", that is the images of Kokserek and a white she-wolf. (Tusupova, 2011, pp. 72-79) Lacunas which are read only in the context of archaic totemic traditions of the Turkic people who know the she-wolf as the primogenitor are also used in Auezov's animalistic story. So, the totemic cult states the following: a direct look into the eyes of a totemic animal is an exchange of forces, unification at the level of inexpressible arhaics. (This archetype was recommended in Zhaksylykov's research) (Zhaksylykov, 2013, p. 312) The other marker is leaping of a wolf over a body of another living being is a statement of the status as a superior force, a mercy and saving lives of the weak. One can see it from the hunters' observations of the lives of wolves. Therefore, jumping over Avdii as if Akbara spares him, giving life, at the same time confirms own status. What status? In a symbolical context of the novel Akbara and Tashchainar are totemic animals, mythological ancestors of the Turkic people. Their tragedy and death is considered as a destiny of the archaic tengrianism which has faced Islam, Christianity and Marxism in the global arena. However, if consciousness of a person is alive, archaics lives as well. Archaics is moral imperatives, eternal laws of human life in wildlife to some extent. It is typical that Boston Urkunchiev, the positive hero of the novel appears the carrier of an archaic imperative. He aspires to return the wolf cubs stolen by Bazarbai in Akbara and Tashchainar's den, he tries to restore the lost balance with the nature. However, the continuous chain of Boston's evil leads to full social defeat, and this defeat is reflected in the loss of his friend, Ernazar, the death of his wife, the death of his small son and inevitable imprisonment. This destiny is brought to Boston by Akbara who glanced into the eyes of the dying Avdii that is why the spiritual continuity of the good and the evil in the dialectic interrelation is used by the writer and in text lacunas. Though Avdii had no pupils, future apostles, his victim was noticed, it was seen by the nature (Butterfly Effect-A $\mathrm{Zh}$.) Therefore such significant action couldn't but be reflected in a pattern (network) of spatial live substance. Otherwise it can't be, otherwise we won't understand why Akbara did not want to meet Avdii, the naked, defenseless adolescent and why the maternal instinct was awaken in her with such force when she saw the child, Boston's son and wanted to take him away as her own puppy into the den.

Akbara's she-wolf stands in the same line as the Horned deer-mother in the story "The White ship" ("After the fairy tale" - A.Zh.). The contextual, symbolical sense of these images is read clearly enough: these images are forms of the mythological foremother of all mankind-Ak ene is more ancient than Tengri-Umai, Shiva Cali-Durga, Vaal-Ashtarta and other god personification. Avdii's death is internally connected with Akbara's death. It is a plan of relations and interrelation of two global doctrines, archaic and new testament, the tragic aspect of the continuous denial and interrelation of ideologies because nothing arises from nothing, trampling down death by death, new is born as the updated old.

Boston is not Avdii, he is the other human, the spiritual alternative who is more traditional and recognizable. Boston can't spare and forgive Bazarbai (some kind of Judas-A. Zh.) His revenge is natural and the same time clearly helpless. The chain of the evil is continuous, moves on the returnable line, and with the murder of Bazarbai this energy will proceed. Besides, we should not forget about such words told in Dhammapada: "Hatred never wins hatred but only love wins hatred"(Dhammapada, 1960, p. 48)

The mythological thinking exists from immemorial times. In archaic times when human communities existed in the form of race and tribes, the mythological thinking prevailed over all other types of thinking of the ancient man.(Freidenberg, 1978) Spiritual culture of ancient communities was based on myths: solar and lunar, astral and genealogical, topological and totemic, calendar and etc. (Tokarev, 1990, p. 622) The mythological principle conceptualizing the origin of space, the sky and the earth, water, animals and plants and the human being applied for a role of the first ideologeme. The primitive man needed to know where things originated from and who created the world. Myths explained, named creators, regulated the way of the human being in difficult, unclear space, gave laws and formulated a taboo (ban). Some tribes considered the creator of the world to be an animal, in this regard totemic cult was formed. The organizer of the world was often considered as this or that zoomorphic creature by the islands people of the World Ocean or the boundless jungles. It is an era of formation of the most ancient animism. The data of anthropology show that the history of a Cro-Magnon who appeared more than 150000 years was usually accompanied by various cults since the period of his emergence on the Earth. (Tailor, 1989) Traces of these cults are noticeable in the funeral customs of a Cro-Magnon. Thus, the myth 
as verbal reflection of a cult continuously accompanied the ontogenesis of a Cro-Magnon. It enables us to say that the myth served as the internal principle of socialization of communities of the primitive man, of their stratification and organization. The mythological layer went to consciousness of the man, only doctrines of world religions and ideology of socio-political doctrines were left in the minds of the man. However, they bear traces of ancient myths in their heart. The world literature bears these traces as well, and the mythological paradigmatics is often paradoxical.

As it was stated in the works of anthropologists, one of the important consequences of the myth function in ancient communities was ban on blood mixture. (Tokarev, 1990, p. 622) It is known that incest is avoided not only by people, but also animals. An instinct against incest is very ancient and constant; of course, it is the natural mechanism of the survival of the populations, operating among animal species. However, a reasonable living being, the human being sometimes establishes his own rules and they often contradict to natural laws, acting against of an instinct but nevertheless, providing the survival in exceptional circumstances. The ban on incest is the fundamental, basic law, it is almost an instinct. However, in rare cases, when almost the whole tribe perished, and only some men and women, relatives survived, the ban on incest was lifted for the sake of procreation. This case of lifting a ban is coded in the myth structure of the horned Deer-mother reproduced in Chingiz Aitmatov's story "The white Ship". We briefly retell a plot of this myth. Couple thousand years ago the Kyrgyz lived in Siberia on the river bank Anasay (Yenisei). They were aggressive and often attacked the neighboring tribes. The fatal destiny overtook them as well. Once, when the Kyrgyz were occupied with a funeral of the leader, enemies attacked a defenseless tribe and destroyed it. There were two children alive, the boy and the girl who walked in the woods. It isn't specified that they were siblings in Ch. Aitmatov's text, but the myth doesn't exclude it but assumes it. Various versions of the similar myth of other nations serve as confirmation. Besides we see that the horned Deer-mother becomes for them a mother that makes them a brother and a sister. The prevention of the Speckled Lame Old woman did not stop her (the archaic foremother of all living being-A. $\mathrm{Zh}$.) that descendants of these children, that is people, will begin to kill deer and eat them.

Who are you? Why do you speak the human language?-Speckled Lame Old woman asked.

- I am a deer-mother, - she answered.-And I started talking in this way because you won't understand me, you won't listen to me.

- What do you want, deer- mother?

- Let the children go, big wise woman. Give them to me, please.

- Why do you want them?

- People killed my twins, two deer. I am looking for children.

- Do you want them to bring up?

- Yes, big wise woman.

- Did you think over properly, deer-mother?-Speckled Lame Old woman laughed.-After all they are children of the human being. They will grow up and kill your deer.

- When they grow up, they won't kill my deer, - the Siberian stag answered.-I will be a mother for them, and they will be my children. They will not kill their brothers and sisters, will they? "(Aitmatov, 1971, p. 572)

The speckled Lame Old woman doesn't kill children though khan ordered to do so. Thus, the protection of life and a future foresight, the hidden function of this character that betrays the features of Ak Ene, mother of the whole mankind according to tengrian myths. It is curious that in the majority of the Kazakh magic fairy tales mystan-kempir, zhalmauyz-kempir (baba-yaga) gradually helps the main character. The speckled Lame Old woman and the horned deer-mother are connected with each other in a hidden, ambivalent way. They can appear in the forms of one living being, the eternal maternal beginning.

The plot of Ch. Aitmatov's story "The white Ship" represents an attempt to answer some bewitched questions of the human life clamped between the Good and the Evil. One should consider features of this plot, the development of which is influenced significantly by the totemic myth about the horned Deer-mother. The tiny forest cordon on the slope of one of the mountains that tower over the Lake Issyk Kul is the model of the isolated mankind. Only some people live on this cordon: Orozkul, the horse trainer, grandfather Momyn and grandmother, their seven-year-old grandson, Bekei, Orozkul's wife, she is Momyn's daughter. It is a micro model of the patriarchal society where the man predominates. In a traditional Turkic communal family the oldest man rules. However, in Ch. Aitmatov's model disharmony is obvious, grandfather Momyn is not the head of a small community, the son-in-law, Orozkul governs it controlling the cordon. He rules for the reason that he is strong 
and cruel, if even he is small but the backward chief. Momun is his subordinate, appeared to be a bell boy for his son-in-law for a number of reasons. Firstly, he is a very gentle, appeasable, modest person by character. He obeys Orozkul because of pity to his daughter; Bekei is almost daily beaten by her husband. The compassion to the daughter, fear that the second daughter will be divorced, make Momun weak, compliant. He forgives Orozkul's beating, cruelty, rough reproaches, and boorish behavior. Besides, he feels guilty before Orozkul, because his daughter can't give birth to a son and have the successor. And this situation continues for years. Scandals in the family of the son-in-law and beating of the daughter cause Momun intolerable sufferings. Trying to understand why Bekei and Orozkul have no children, he looks for the answer and finds the explanation in futility of the daughter. In his opinion descendants of adopted children of the horned Deer-mother are guilty in this evil, they were the first who started killing deer. Deer took offense at people and left these woods, they don't bring a cradle on the horns any more. The evil started growing among people, strengthening and making them meet each other. The murder of deer, the offspring of the horned Deer-mother is some kind of the first sin of people with which the evil history begins. Here the first bible sin appears to be obvious analogy. (Mahabharata, 1987, p. 326)

Momun's heart is aimed at the mythological world, at a fairy tale and beauty monastery where the character of a great totem, the horned Deer-mother, would explain and reconcile everything. Questions aren't necessarily asked in this world, there is no need to strain. This world doesn't demand anything from him, except pure belief. Therefore Momun is a mythological, patriarchal person, having executed belief in the horned deer-mother. This character faces the past in topos of the work. He carries an ideological charge of the archaic past.

He is nobody and nothing in the present world. His legends cause laughter and Orozkul's irony. The real sadist is hidden in Orozkul. Mocking at the naive, helpless old man, forces him to shoot the Deer-mother noticed in the wood. The myth of the old man is dangerous for Orozkul because this world denies him, there is no place for him in it. The moral of the myth and Orozkul's hypertrophied egoism are absolutely incompatible. Orozkul, the declassed, marginal personality is the generation of the demythologized present.

Even if he had a child, he would be still cruel. His nature is the evil, vindictiveness. The absence of children is only the reason to give way to anger. Its beginning is deeper, it is his offense on the world for his personal implementation failure and for lack of demand. Once he was the chief of regional scale, he was lowered for self-interest, then he was sent to a forest cordon. The main reason of his constant anger is vindictive, bitter offense for his estrangement. Thus, Orozkul is the carrier of the ambitious ego, suffering an inferiority complex. Of course such a narrow ego and the myth are eternal antagonists.

Orozkul is also acquainted with ancient patrimonial myths. The inner world of the Kyrgyz old times is known to him. However, it is alien to him because it seems absolutely useless. The special charge of hatred to altruism of the myth, intolerance to his spirituality is also hidden in him. Orozkul is the ideologist of the other world, the habitat where calculation, careerism, aspiration to have power dominates. He is the potential tyrant; he needs to succeed in any way.

Why does Orozkul force grandfather Momun to shoot at a deer? Probably, there is something that is much stronger than him. On the one hand it is personal hatred to people of the patriarchal belief, from his point of view, the belief that is naive, useless. Besides, he cannot understand such people as Momun. Unselfishness, artlessness, spontaneous kindness is unfamiliar to him as well. In the depth of his heart he understands his own lameness because he sees that naive and pitiful Momun is sometimes happy. It is the key to secrets of his character. Orozkul is separated from happiness not because he has no children but for deeper reason. He is a bad person by nature. Bad for the reason that he is created out of tradition, out of myth influence. Here we find Aitmatov's significant moral criterion: the people, aloof from the myth, the fairy tale, spirituality are the people who are lost for good. Thus, the myth is a primordial matrix of moral, spirituality, kindness and belief. Losing faith to ancient ideals, the person is depersonalized. The emptiness formed in the soul of the demythologized person, is populated by demons of the evil. This important Aitmatov's idea will have further development in a number of his works, especially in novels.

Thus, Orozkul needs to expose the myth but in a special way. The myth needs to be destroyed in the soul of the believer, but it is better to make all this by the efforts of the believer himself. There is a difficult, paradoxical situation in the story. Orozkul, sneering at Momun, mocking him, finally, forcing him to kill a totemic animal, acts as a medieval inquisitor. One should not forget, the deer for Momun is a live fetish. The old man managed to infect his grandson with belief in the horned Deer-mother, that led the boy into the fairy tale world, and it is a special philosophical subject. The function of grandfather Momun is esthetically difficult after all he has the role of a hidden storyteller in the story. As a storyteller, he recovers fetishes and brings them to a scene. Physically 
ailing, weak old man is spiritually strong and strategically active in an ideological sphere of the work. He has only one opportunity to resist Orozkul in his field-to revive the myth and to force people to believe in it. As a storyteller he acts in a complex way, changing constitutive topos, however he doesn't realize it as a character. To captivate and disarm the enemy's idea, to force him to believe in the myth, - isn't it an old strategy of all believers, trying to be socialized? Now we understand that the ideology is rather a powerful and sophisticated form of the total weapon. It was applied before the XX-century

\section{Conclusions}

Both Momun and Orozkul are guilty in the death of the boy, this is a paradoxical logic of the mythological poetic plot. Both of them realized the myth prediction through the words of the Speckled Lame Old woman: one killed a deer physically, a shot from a gun, having betrayed the fairy tale and belief in her, the other committed it expecting murder and steadily leading to it, reading motives in the soul of the subordinated person, acting as a ideologist of anger. This fatal shot as if flown off in topos of the work, have struck other hero, the boy. Here the other complicated idea is invisibly born, the attempt to kill the myth is a special evil with the chain reaction of infinite consequences. After all the ancient myth is a genesis of spirit, the good, and the belief. Therefore, the attempt on trust, this is a crime against man's inner world, the action which is infinitely crushed and split by polarities which in turn lead to unpredictable fatal results. The crash of the ideology of the Bolshevism is not a significant symbol, isn't it? After all Bolsheviks began destroying traditional religions, temples and believers. It was the total action which captured half of the planet and it ended disgracefully. Connecting the myth with the reality in his works, Ch. Aitmatov took an advantage over the myth's potential. A. Bocharov in his turn wrote: "The most fruitful way Ch. Aitmatov chose for him is through application of mythologemes-mythological structures which enable to reveal the first forms of human being". (Bocharov, 1997, pp. 65-108)

The XX-century is a century of collisions of ideologies, deep breaks and the movement of mythological matrixes. The fight of myths and ideas influences the destiny of the modern mankind with a big force.

B. Y. Tolmachev sums up the source of literature that the artist is a conceptualist and romantic thinker with terrific dramatic force of narration Ch. Aitmatov gave a splendid opportunity for the Kirgiz literature to be seen on the world arena. (Tolmachev, 1998, p. 233)

\section{References}

"A Little Grain of the Word of Vissarion Presenting the Last Testament of the Heavenly Father who Sent Him" Coll. (1993)

Aitmatov, Ch. (1971). Stories (pp. 72-77). Kyrgyzstan.

Aitmatov, Ch. (1971). The Scaffold (p. 572). Alma-Ata: Zhalyn.

Bocharov, A. (1997). Literature issues, 5, 65-108.

Bulgakov, M. (1987). Master and Margarita.

Capra, F. (2003). "The Web of Life” (p. 336). K.: Sofia.

Dhammapada. (1960). M.: Nauka.

Freidenberg, O. M. (1978). Myth and literature of the ancient times (p. 605). M.: Nauka.

Mahabharata. (1987). Book Forest (aranyaka parva) (p. 326). Moscow: Nauka.

Mann, T. (1991). Josef and his brothers (1st ed., p. 720). M.: Pravda.

Muchnik, G. M. (1995). Challenges of communicative poetics (p. 181). Almaty: pub. House KazNU.

Schure, E. (1990). Great devotees (p. 419). M.: "Book-Printshop".

Tailor, S. A. (1989). Culture (p. 573). M.: Poliizdat.

Tokarev, S. A. (1990). Earlier forms of religions (p. 622). M.: Politizdat.

Tolmachev, B. Y. (1998). Connection of the worlds. About the contemporary historical and literal prose (p. 233). Almaty: KazNU.

Tusupova. (2011). A. K. Man and the nature in the works of M. Auezov. D. London, Ch. Aitmatov-Dynamics of literature process and the issues of poetics. Proceedings of international conference (pp. 72-79). Almaty: KazNU.

Zhaksylykov, A. Zh. (2013). Comparitive typology of images and motives with religious content in the works of the Kazakh literature (p. 329). Aesthetics, genesis. Almaty: Kazakh University. 
Zhaksylykov, A. Zh. (2013). Literally translation and literal process (p. 312). Almaty: Tanbaly.

Zhetpisbaeva, B. A. (1999). Symbol in the movement of the literature (p. 288). Almaty: Galim.

\section{Copyrights}

Copyright for this article is retained by the author(s), with first publication rights granted to the journal.

This is an open-access article distributed under the terms and conditions of the Creative Commons Attribution license (http://creativecommons.org/licenses/by/3.0/). 